DOI: 10.1002/adsc.200((will be filled in by the editorial sttaff))

\title{
Palladium Nanoparticles in Water: A Reusable Catalytic System for the Cycloetherification or Benzannulation of $\alpha$ - Allenols
}

\author{
Benito Alcaide, ${ }^{\mathrm{a} *}$ Pedro Almendros, ${ }^{\mathrm{b} *}$ Ana M. González, ${ }^{\mathrm{a}}$ Amparo Luna, ${ }^{\mathrm{a}}$ and Sagrario \\ Martínez-Ramírez
}

a Grupo de Lactamas y Heterociclos Bioactivos, Departamento de Química Orgánica I, Unidad Asociada al CSIC, Facultad de Química, Universidad Complutense de Madrid, 28040 Madrid, Spain, Fax: (+34) 91-3944103, E-mail: alcaideb@quim.ucm.es

b Instituto de Química Orgánica General, Consejo Superior de Investigaciones Científicas, IQOG-CSIC, Juan de la Cierva 3, 28006 Madrid, Spain, Fax: (+34) 91-5644853, E-mail: Palmendros@iqog.csic.es

c Instituto de Estructura de la Materia, Consejo Superior de Investigaciones Científicas, IEM-CSIC, Serrano 121, 28006 Madrid, Spain

Received: ((will be filled in by the editorial staff))

Supporting information for this article is available on the WWW under http://dx.doi.org/10.1002/adsc.200\#\#\#\#\#.((Please delete if not appropriate))

Abstract. A convenient ligand free catalytic system has
been developed for the chemoselective cyclization reaction
of various $\alpha$-allenol derivatives by palladium nanoparticles
(PdNPs) in an aqueous reaction medium.
Kevwords: allenes; cyclization; environmental
chemistry; heterogeneous catalysis; palladium

Allenes, a class of compounds with two cumulative carbon-carbon double bonds, are versatile synthetic intermediates in organic synthesis. ${ }^{[1]}$ Metal nanoparticles have recently received considerable attention in organic synthesis because of their efficient catalytic activity. ${ }^{[2]}$ In contrast, there is lack of information for the reactivity of the allene moiety in presence of metal NPs. Among the different metallic nanocatalysts, palladium nanoparticles (PdNPs) have generated a huge interest. ${ }^{[3]}$ Traditional Pd-catalyzed reactions often require the use of expensive and unstable ligands. Thus, the use of ligand-free heterogeneous Pd catalysts is highly desirable. Besides, the use of heterogeneous catalysts considerably reduces the residual metal impurities in the products. The solvent used for the catalytic reaction is very important from the perspective of preservation of the integrity of the nanocatalytic species. Water has gained a lot of attention in the recent times because of the appealing properties of organic reactions in aqueous media from both the economical and "green chemistry" points of view. ${ }^{[4]}$

The dihydrofuran motif has attracted much interest because of both the biological activity of naturally occurring representatives as well as its synthetic versatility as building block. ${ }^{[5]}$ Transition metal-catalyzed cycloetherification of allenols is one of the most rapid and convenient methods for the preparation of oxacycles. ${ }^{[6]}$ The synthesis of the relevant carbazole nucleus ${ }^{[7]}$ has also been accomplished through precious metal-catalyzed carbocyclization/dehydration of allenols. ${ }^{[8]}$ However, the expensiveness of gold and platinum catalysts makes their use often impractical in larger scale synthesis. Besides, previous reported methods are homogeneous which circumvents the noble metal catalyst recycling, thus diminishing their applications. It has been reported for classical $\mathrm{C}-\mathrm{C}$ bond-forming reactions that the use of water instead of organic solvents improved the catalytic activity of PdNPs, because palladium clusters which could be stabilized in water were found to be the catalytically active species for ligand-free palladium-catalyzed cross coupling reactions. ${ }^{[9]}$ We envisioned that the oxycyclization or benzannulation of the allenol moiety might be achieved utilizing a reusable metal catalyst in water. Herein, we present a convenient cyclization of allenols towards the preparation of dihydrofurans and carbazoles catalyzed by PdNPs. ${ }^{[10]}$

Table 1 PdNPs-catalyzed oxycyclization reaction of $\alpha$ allenol $\mathbf{1} \mathbf{a}^{a}$<smiles>C=C=C(C)C1(O)C(=O)N(C)c2ccccc21</smiles>

$1 \mathbf{a}$
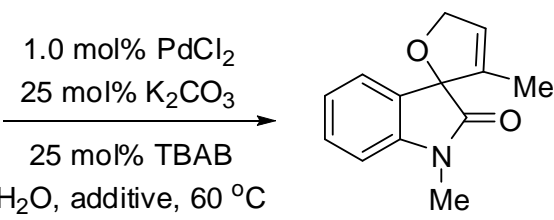

$2 \mathbf{a}$

\begin{tabular}{cccc}
\hline Entry & Additive & t (h) & $\begin{array}{l}\text { Yield } \\
(\%)^{b}\end{array}$ \\
\hline 1 & phenol & 3.5 & 10 \\
2 & 4-nitrophenol & 24 & 11 \\
\hline
\end{tabular}


${ }^{a} \mathrm{~A}$ precatalytic approach was used for the generation of the palladium nanoparticles. ${ }^{b}$ Yield of pure, isolated product $\mathbf{2 a}$ after silica gel chromatography with correct analytical and spectral data.

To test the reactivity of the $\alpha$-allenol moiety, several conditions were screened. Allene 1a was chosen as a model substrate for the PdNPs-catalyzed oxycyclization reaction. There are several key experimental parameters that determine the formation of PdNPs including reducing agent, solvent, surfactant, and temperature. There are also two different approaches for the preparation of PdNPs, namely, in situ and precatalytic generation. In our typical optimized generation of PdNPs, $\mathrm{PdCl}_{2}$ was used as the Pd precursor, $\mathrm{K}_{2} \mathrm{CO}_{3}$ was selected as the reducing agent, water was used as the solvent, and TBAB (tetrabutylammonium bromide) as the surfactant. The solution of $\mathrm{PdCl}_{2}$ turns into a black heterogeneous mixture due the presence of both $\mathrm{K}_{2} \mathrm{CO}_{3}$ and TBAB, which implied the formation of PdNPs as checked by using transmission electron microscopy (TEM) as analytical technique (Figure 1). Disappointingly, the reaction of allenol 1a in the presence of PdNPs did not occur, recovering unaltered the starting material. Happily, the addition of a stoichiometric amount of phenol to the reaction system, results in an unanticipated benefit for the cycloetherification reaction. While PdNPs generated in situ in the presence of phenol could catalyze the cycloetherification reaction of 1a to 2,5-dihydrofuran 2a in a very poor $3 \%$ yield, the pre-generated PdNPs in the presence of phenol gave the desired product 2a in a more promising $10 \%$ yield (Table 1 , entry 1 ). Among the different phenol derivatives tested, 4bromophenol was encountered as the better performance, rendering $\mathbf{2 a}$ in a $80 \%$ yield (Table 1 , entry 4). 4-Bromophenol was recovered unaltered as stoichiometric product at the end of the reaction. No phenol derivative was identified as a side reaction product. The palladium source $\mathrm{PdCl}_{2}$ was used in 1.0 mol \%. The conversion of $\alpha$-allenol 1a to oxacycle $\mathbf{2 a}$ at $20{ }^{\circ} \mathrm{C}$ is less than $5 \%$, but it can reach up to $80 \%$ at $60{ }^{\circ} \mathrm{C}$ (reaction time $1 \mathrm{~h}$, additive: 4-bromophenol). Consequently, it may be inferred that higher temperature is beneficial to the catalytic activity of the PdNPs.

Under the present study it appears that the $\mathrm{K}_{2} \mathrm{CO}_{3}$ should act as the reducing agent to form the PdNPs from the pre-catalyst $\mathrm{PdCl}_{2}{ }^{[11]}$ To prove this, the cyclization reaction of $\alpha$-allenol 1a was performed in the absence of $\mathrm{K}_{2} \mathrm{CO}_{3}$ under otherwise identical conditions. In the event, just 5\% yield of the desired product 2a was isolated after $3 \mathrm{~h}$ of reaction. The PdNPs were not formed in the absence of $\mathrm{K}_{2} \mathrm{CO}_{3}$ as in this case no visual formation (non-existence of blackening at the reaction mixture) was observed and little reaction took place.

In the absence of 4-bromophenol the reaction of allenol 1a in the presence of PdNPs did not occur, thus

highlighting the crucial role of this additive in our catalytic system. This result suggests that the phenol acts as a ligand to the palladium active species. The proposed charge transfer interaction between PdNPs and the aromatic ring of 4-bromophenol has been invoked based on previous literature reports on cation$\pi$ interaction. $^{[12]}$

It is well known that the use of a stabilizer is essential to prevent agglomeration of the metal NPs. ${ }^{[13]}$ Tetraalkylammonium stabilizers act through electrostatic and steric interactions. Taking into account the poor results in the absence of TBAB, it should impart electrosteric (combination of steric and electrostatic) stabilization.

With the optimized reaction conditions in hand we then examined the scope and generality of the PdNPs-catalyzed method. Various alkyl- and arylsubstituted $\alpha$-allenols $\mathbf{1 b}-\mathbf{j}$ were reacted to give a range of 2,5-dihydrofurans $\mathbf{2} \mathbf{b}-\mathbf{j}$, serving the above process as a general approach to 2,5-dihydrofurans (Scheme 1). Both electron-donating (OMe) and electron-withdrawing substituents $(\mathrm{Cl}, \mathrm{Br}$, COOMe, $\mathrm{CN}$ ) on the aromatic rings were tolerated. The above observation points to the great activity under mild conditions of nanosized palladium particles as heterogeneous catalyst in aqueous environment.

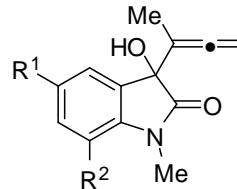

1b $\mathrm{R}^{1}=\mathrm{Cl}, \mathrm{R}^{2}=\mathrm{H}$ 1c $\mathrm{R}^{1}=\mathrm{Br}, \mathrm{R}^{2}=\mathrm{H}$ 1d $\mathrm{R}^{1}=\mathrm{H}, \mathrm{R}^{2}=\mathrm{Cl}$<smiles>[R]c1cc(C(O)C(F)=C=C)cc([R])c1[R]</smiles>

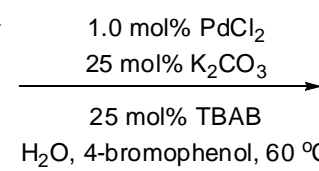

1e $\mathrm{R}^{1}=\mathrm{H}, \mathrm{R}^{2}=\mathrm{Cl}, \mathrm{R}^{3}=\mathrm{H}, \mathrm{R}^{4}=\mathrm{Me}$

If $\mathrm{R}^{1}=\mathrm{H}, \mathrm{R}^{2}=\mathrm{OMe}, \mathrm{R}^{3}=\mathrm{H}, \mathrm{R}^{4}=\mathrm{Me}$

1g R $\mathrm{R}^{1}=\mathrm{OMe}, \mathrm{R}^{2}=\mathrm{H}, \mathrm{R}^{3}=\mathrm{OMe}, \mathrm{R}^{4}=\mathrm{Me}$

1h $R^{1}=H, R^{2}=$ COOMe, $R^{3}=H, R^{4}=M e$

1i $\mathrm{R}^{1}=\mathrm{H}, \mathrm{R}^{2}=\mathrm{CN}, \mathrm{R}^{3}=\mathrm{H}, \mathrm{R}^{4}=\mathrm{Ph}$
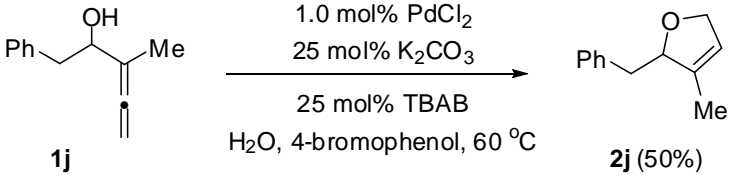

Scheme 1. Synthesis of 2,5-dihydrofurans $\mathbf{2 b}-\mathbf{i}$ through PdNPs-catalyzed oxycyclization reaction of $\alpha$-allenols $\mathbf{1 b}$ i, 2b: 1.5 h; 2c: 3 h; 2d: 2 h; 2e: 3.5 h; $2 f: 4$ h; 2g: 6 h; 2 h: 8 h; $2 \mathbf{i}: 2$ h; $2 \mathbf{j}: 3$ h.

Next, the challenging $\alpha$-hydroxyallenyl-tethered indoles $1 \mathbf{k}-\mathbf{n}$ were selected as systems to explore the catalytic activity of PdNPs. $\alpha$-Hydroxyallenyl-C3tethered indoles $\mathbf{1 k}$ and $\mathbf{1 l}$ reacted to afford 
cycloetherification products $\mathbf{2 k}$ and $\mathbf{2 l}$ in reasonable yields (Scheme 2). The above transformation (Schemes 1 and 2) tolerates precursors that contain Cland $\mathrm{Br}$-substituted aryl rings (1b-e and $\mathbf{1 l}$ ), which could suffer a Heck-type reaction with the allene moiety. Interestingly, when $\alpha$-hydroxyallenyl-C2tethered indoles $\mathbf{1 m}$ and $\mathbf{1 n}$ were employed as substrates, the reaction failed to afford 2,5dihydrofuran products, and carbazoles $\mathbf{3 m}$ and $\mathbf{3 n}$ were obtained instead (Scheme 2). For thoses cases, $C$ cyclization was favoured over $O$-cyclization. Besides, the PdNPs-catalyzed oxy- or carbocyclization reactions of indole precursors 1 occurred without harming the sensitive indole ring. As a consequence of the high surface area of nanoparticles, the required catalyst concentration is lesser. Thus, the cyclization of $\alpha$-allenols 1 can be achieved using just $1.0 \mathrm{~mol} \%$ of one of the most economical source of palladium, $\mathrm{PdCl}_{2}$.
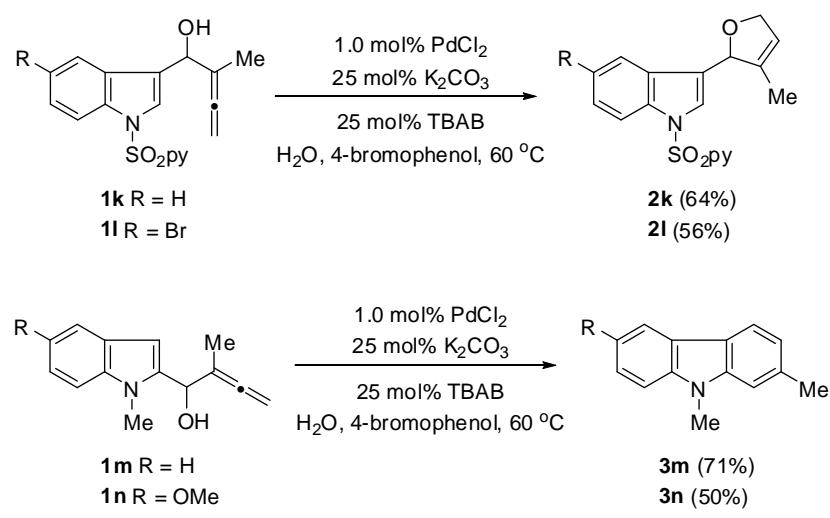

Scheme 2. Synthesis of 2,5-dihydrofurans $\mathbf{2 k}, \mathbf{l}$ and carbazoles 3m,n through PdNPs-catalyzed cyclization reaction of $\alpha$-allenols 1k-n, 2k: 24 h; 2l: 24 h; 3m: 3.5 h; 3n: 5 h; py = 2-pyridyl.

The characterization of PdNPs was carried out by using transmission electron microscopy (TEM) as analytical technique. Thus, it was shown that the obtained $\operatorname{Pd}(0)$ particles are in the nano region with an average size of $2.2 \mathrm{~nm}$ (Figure 1 and Figure 2). ${ }^{[14]}$ The electron dispersive X-ray (EDX) spectrum confirmed that the metal component of our nanoparticles is palladium (Fig. S1, see Supporting Information).

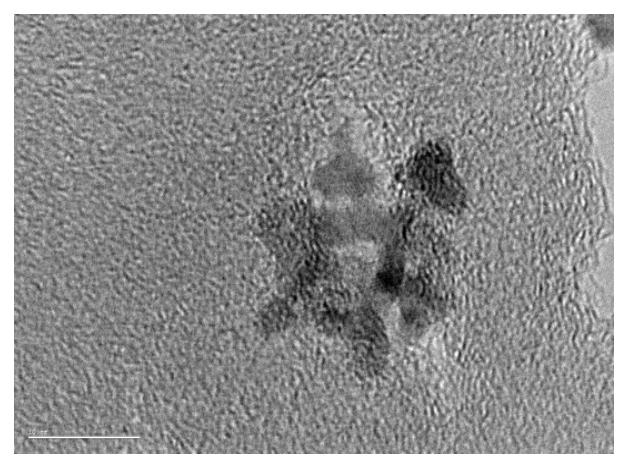

Figure 1. TEM image (JEOL-JEM-2100) of the pregenerated PdNPs (magnification $=600000)$.

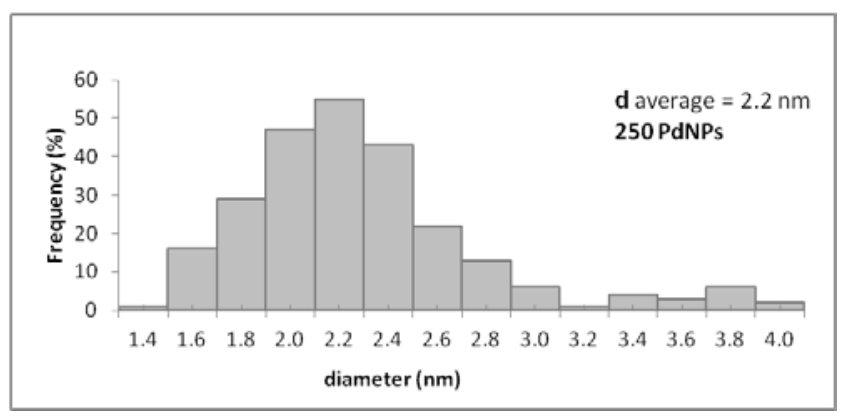

Figure 2. Histogram of the pre-generated PdNPs.

To study the recyclability of the PdNPs, when the reaction of $\alpha$-allenols $\mathbf{1 a}$ and $\mathbf{1 b}$ has gone to completion, the mixture was allowed to cool to room temperature and the catalyst was recovered by centrifugation. Then, the solid was washed with water and acetone, dried under reduced pressure and reused for further oxycyclization reactions. A high level of catalytic activity was retained in the PdNPs at least after four cycles, because 2,5-dihydrofurans $\mathbf{2 a}$ and $\mathbf{2 b}$ were obtained in similar yields even in the fourth recycling as shown in Table 2.

Table 2 Catalyst recovery from the PdNPs-catalyzed oxycyclization reaction of $\alpha$-allenols $\mathbf{1}^{a}$<smiles>[R]c1cc([R])c2c(c1)C(O)(C(=C)C)C(=O)N2C</smiles>

1a $\mathrm{R}^{1}=\mathrm{H}, \mathrm{R}^{2}=\mathrm{H}$ 1b $\mathrm{R}^{1}=\mathrm{Cl}, \mathrm{R}^{2}=\mathrm{H}$

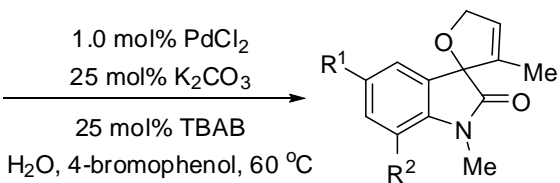

2a

\begin{tabular}{cccc}
\hline Cycle & Product & ${\text { Yield }(\%)^{b}}^{\text {Catalyst Recovery }}$ & $\begin{array}{c}\text { (\%) } \\
\text { Native }\end{array}$ \\
1 & 2a & 80 & 96 \\
2 & 2a & 78 & $91^{c}$ \\
3 & 2a & 75 & $88^{c}$ \\
Native $^{a}$ & 2a & 71 & $80^{c}$ \\
1 & 2b & 59 & 95 \\
2 & 2b & 58 & $90^{c}$ \\
3 & 2b & 56 & $86^{c}$ \\
\hline
\end{tabular}

${ }^{a}$ PdNPs were generated through a precatalytic approach. ${ }^{b}$ Yield of pure, isolated product 2 after silica gel chromatography with correct analytical and spectral data. ${ }^{c}$ With recovered catalyst.

The above results point to a good retention factor of palladium in the cyclization reactions, because catalyst leaching should be accompanied of diminished catalytic activity after recycling. The experiments using $\mathbf{1 a}$ and $\mathbf{1 b}$ proved the ability of the PdNPs to be recycled because the cyclization reaction was iteratively repeated using the same batch of catalyst. TEM studies of fresh and reused catalysts after the 
fourth cycle point to the unchanged nanoparticle size before and after the cyclization reaction (Fig. S2, Fig. S3, Fig. S4, Fig. S5, Fig. S6, Fig. S7, see Supporting Information).

Micro-Raman spectroscopy was used to analyze the possible presence of embedded TBAB in the PdNPs. Raman spectra were obtained using two excitation wavelengths (532 and $633 \mathrm{~nm}$ ) and making power scans of $2.5 \mathrm{~mW}$ and $25 \mathrm{~mW}$, respectively, to select the best conditions of register for each wavelength. Figure 3 shows Raman spectra of TBAB (red line), allenol 1a (black line), precatalytic generated PdNPs (sky blue line), recycled (one cycle) PdNPs washed with water and acetone (cobalt blue line), recycled (one cycle) PdNPs without washing with water and acetone (green line). In the light regions, no TBAB was detected in the spectra of the PdNP samples, indicating the absence of $\mathrm{TBAB}$ in the metallic catalyst.

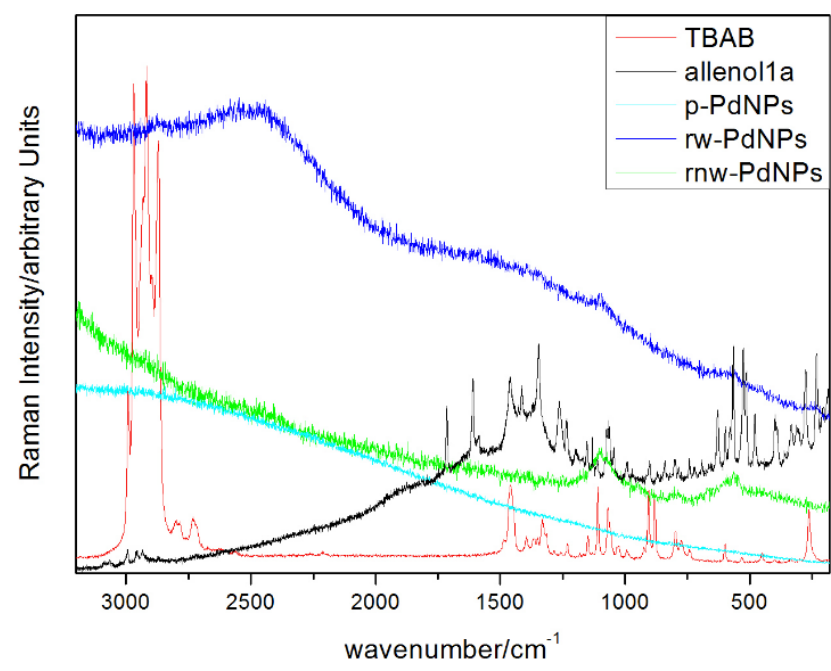

Figure 3. Raman spectra recorded using a wavelength of $532 \mathrm{~nm}$ (except for allenol 1a which required $633 \mathrm{~nm}$ ). All the Raman spectra were normalized to the maximun intensity.

For the oxycyclization reaction of allenol 1a, we detected that the dihydrofuran formation catalyzed by PdNPs was faster than this catalyzed by homogeneous $\mathrm{PdCl}_{2}$. Thus, the turnover frequency (TOF) of the catalyst for the heterogeneous $\mathrm{C}-\mathrm{O}$ bond formation was 155-fold higher than that for the homogeneous catalyst. ${ }^{[15]}$ These results demonstrate improved efficiency of PdNPs over homogeneous catalysis in this particular reaction. By contrast, it was observed that cyclization/coupling reaction sequences of allenols 1 with unsaturated halides were not feasible. The mixture of allenol 1a either with allyl bromide or iodobenzene under PdNPs-catalyzed conditions was non-productive for the oxycyclization/cross-coupling adduct formation.

In conclusion, the activity of palladium nanoparticles (PdNPs) as a convenient catalyst for the chemoselective cyclization reaction of various $\alpha$ - allenol derivatives in water under ligandless conditions has been disclosed. The heterogeneous catalyst also offers the advantages of recyclability, ease removal, and high turnover frequency that the homogeneous catalyst.

\section{Experimental Section}

General methods: ${ }^{1} \mathrm{H}$ NMR and ${ }^{13} \mathrm{C}$ NMR spectra were recorded on a Bruker AMX-500, Bruker Avance-300, or Varian VRX-300S. NMR spectra were recorded in $\mathrm{CDCl}_{3}$ solutions, except otherwise stated. Chemical shifts are given in ppm relative to TMS $\left({ }^{1} \mathrm{H}, 0.0 \mathrm{ppm}\right)$, or $\mathrm{CDCl}_{3}\left({ }^{13} \mathrm{C}, 77.0\right.$ $\mathrm{ppm})$. Low and high resolution mass spectra were taken on an AGILENT 6520 Accurate-Mass QTOF LC/MS spectrometer using the electrospray mode (ES) unless otherwise stated. IR spectra were recorded on a Bruker Tensor 27 spectrometer. The transmission electron microscopy (TEM) analysis was performed on a JEOLJEM-2010 microscope using a $200 \mathrm{kV}$ voltage. Dispersive Raman spectra at 633 and $532 \mathrm{~nm}$ were recorded in a RM 1000 Renishaw Raman Microscope System. The Raman spectrometer is equipped with a Leica microscope and an electrically refrigerated CCD camera. The spectra were obtained with $\times 50$ magnification objective lenses. The final spectra were the result of 10 accumulations to improve the signal-to-noise ratio and the integration time was $10 \mathrm{~s}$. The software employed for data acquisition and analysis was Wire for Windows and Galactic Industries GRAMS/32TM. Five scans were recorded to improve the signal-to-noise ratio. The Raman shift was calibrated before the measurements according to the silicon peak at $520 \mathrm{~cm}^{-1}$. The $633 \mathrm{~nm}$ line had a laser power from 0.25 to $25 \mathrm{~mW}$ and finally, the $532 \mathrm{~nm}$ line had a laser power from 0.0005 to $5 \mathrm{~mW}$. The measurements were done directly in the sample (in situ), the sample preparation is not necessary. All commercially available compounds were used without further purification.

\section{Typical procedure for cyclization of allenols using in situ generated PdNPs.}

To a magnetically stirred solution of tetrabutylammonium bromide (TBAB) $(0.25 \mathrm{mmol}), \mathrm{PdCl}_{2}(0.01 \mathrm{mmol})$ and $\mathrm{K}_{2} \mathrm{CO}_{3}(0.25 \mathrm{mmol})$ in $\mathrm{H}_{2} \mathrm{O}(4 \mathrm{~mL})$ were added the corresponding allenol 1 (1 mmol) and 4-bromophenol (1 mmol) at $60{ }^{\circ} \mathrm{C}$. Upon completion of the reaction (monitored by TLC), the reaction mixture was allowed to cool to room temperature, was diluted with ethyl acetate (3 $\mathrm{x} 5 \mathrm{~mL}$ ), and the ethyl acetate layer was separated from the aqueous layer. The organic extract was dried over anhydrous $\mathrm{MgSO}_{4}$ and concentrated under reduced pressure. Chromatography of the residue using hexanes/ethyl acetate mixtures gave analytically pure compounds.

\section{Typical procedure for cyclization of allenols using precatalytic generation of PdNPs.}

A solution of tetrabutylammonium bromide (TBAB) $(0.25$ $\mathrm{mmol}), \mathrm{PdCl}_{2}(0.01 \mathrm{mmol})$ and $\mathrm{K}_{2} \mathrm{CO}_{3}(0.25 \mathrm{mmol}$, $)$ in $\mathrm{H}_{2} \mathrm{O}(4 \mathrm{~mL})$ was stirred for fifteen minutes at $60{ }^{\circ} \mathrm{C}$. Then, the corresponding allenol 1 (1 mmol) and 4-bromophenol (1 
mmol) were added. The reaction mixture was stirred at $60{ }^{\circ} \mathrm{C}$ until the starting material disappeared as indicated by TLC. The reaction mixture was allowed to cool to room temperature, was diluted with ethyl acetate ( $3 \times 5 \mathrm{~mL})$, and the ethyl acetate layer was separated from the aqueous layer. The organic extract was dried over anhydrous $\mathrm{MgSO}_{4}$ and concentrated under reduced pressure. Chromatography of the residue using hexanes/ethyl acetate mixtures gave analytically pure compounds. Spectroscopic and analytical data for pure forms of compounds $\mathbf{2}$ and $\mathbf{3}$ follow.

Dihydrofuran 2a. From $40 \mathrm{mg}(0.18 \mathrm{mmol})$ of allenol 1a, and after chromatography of the residue using hexanes/ethyl acetate (1:1) as eluent, gave compound $2 \mathbf{a}(31 \mathrm{mg}, 80 \%)$ as a colorless oil; ${ }^{1} \mathrm{H}-\mathrm{NMR}\left(300 \mathrm{MHz}, \mathrm{CDCl}_{3}, 25^{\circ} \mathrm{C}\right) \delta: 7.32$ (td, $J=7.7,1.2 \mathrm{~Hz}, 1 \mathrm{H}), 7.20$ (d, $J=6.3 \mathrm{~Hz}, 1 \mathrm{H}), 7.07$ (t, $J$ $=7.5 \mathrm{~Hz}, 1 \mathrm{H}), 6.82(\mathrm{~d}, J=7.7 \mathrm{~Hz}, 1 \mathrm{H}), 5.96$ (q, $J=1.5 \mathrm{~Hz}$, $1 \mathrm{H}), 5.01$ and 4.90 (dt, $J=12.4,1.9 \mathrm{~Hz}$, each $1 \mathrm{H}), 3.20$ (s, 3H), 1.42 (m, 3H), ${ }^{13} \mathrm{C}-\mathrm{NMR}\left(75 \mathrm{MHz}, \mathrm{CDCl}_{3}, 25{ }^{\circ} \mathrm{C}\right) \delta$ : 175.6, 144.0, 135.8, 130.0, 128.3, 124.9, 124.4, 123.1, 108.2, 92.4,76.3, 26.3, 11.1; IR $\left(\mathrm{CHCl}_{3}, \mathrm{~cm}^{-1}\right): v$ 1715; HRMS (ES): calcd for $\mathrm{C}_{13} \mathrm{H}_{13} \mathrm{NO}_{2}[M]^{+}$: 215.0946; found: 215.0956.

Dihydrofuran 2b. From $57 \mathrm{mg}(0.23 \mathrm{mmol})$ of allenol 1b, and after chromatography of the residue using hexanes/ethyl acetate (1:1) as eluent, gave compound $\mathbf{2 b}$ (34 $\mathrm{mg}, 59 \%$ ) as a yellow oil; ${ }^{1} \mathrm{H}-\mathrm{NMR}\left(300 \mathrm{MHz}, \mathrm{CDCl}_{3}, 25^{\circ} \mathrm{C}\right) \delta$ : 7.30 (dd, $J=8.3,2.1 \mathrm{~Hz}, 1 \mathrm{H}), 7.18$ (d, $J=2.1 \mathrm{~Hz}, 1 \mathrm{H}), 6.75$ (d, $J=$ $8.3 \mathrm{~Hz}, 1 \mathrm{H}), 5.98(\mathrm{~m}, 1 \mathrm{H}), 5.00$ and 4.90 (dt, $J=12.4,2.0$ $\mathrm{Hz}$, each $1 \mathrm{H}), 3.18$ (s, 3H), 1.44 (q, $J=2.0 \mathrm{~Hz}, 1 \mathrm{H}) ;{ }^{13} \mathrm{C}-$ NMR (75 MHz, $\left.\mathrm{CDCl}_{3}, 25^{\circ} \mathrm{C}\right) \delta: 175.1,142.5,135.2,130.0$, 129.9, 128.6, 125.3, 124.9, 109.2, 92.3, 76.5, 26.4, 11.1; IR $\left(\mathrm{CHCl}_{3}, \mathrm{~cm}^{-1}\right): v$ 1729, 1487; HRMS (ES): calcd for $\mathrm{C}_{13} \mathrm{H}_{13} \mathrm{ClNO}_{2}[M+\mathrm{H}]^{+}$: 250.0635; found: 250.0612 .

Dihydrofuran 2c. From $75 \mathrm{mg}(0.25 \mathrm{mmol})$ of allenol 1c, and after chromatography of the residue using hexanes/ethyl acetate (2:1) as eluent, gave compound 2c (55 mg, 75\%) as a yellow oil; ${ }^{1} \mathrm{H}-\mathrm{NMR}\left(300 \mathrm{MHz}, \mathrm{CDCl}_{3}, 25^{\circ} \mathrm{C}\right) \delta: 7.44$ (dd, $J=8.3,1.8 \mathrm{~Hz}, 1 \mathrm{H}), 7.30$ (d, $J=1.8 \mathrm{~Hz}, 1 \mathrm{H}), 6.70$ (d, $J=$ $8.3 \mathrm{~Hz}, 1 \mathrm{H}), 5.97$ (d, $J=1.3 \mathrm{~Hz}, 1 \mathrm{H}), 4.99$ and 4.89 (m, each $1 \mathrm{H}), 3.17$ (s, 3H), 1.43 (m, 3H); ${ }^{13} \mathrm{C}-\mathrm{NMR}\left(75 \mathrm{MHz}, \mathrm{CDCl}_{3}\right.$, $\left.25^{\circ} \mathrm{C}\right) \delta: 175.0,142.9,135.2,132.8,130.3,127.6,125.3$, 115.8, 109.7, 92.2, 76.5, 26.3, 11.1; IR $\left(\mathrm{CHCl}_{3}, \mathrm{~cm}^{-1}\right): v$ 1730, 1468; HRMS (ES): calcd for $\mathrm{C}_{13} \mathrm{H}_{12} \mathrm{BrNO}_{2}[M]^{+}$: 293.0051; found: 293.0053.

Dihydrofuran 2d. From $40 \mathrm{mg}(0.16 \mathrm{mmol})$ of allenol 1d, and after chromatography of the residue using hexanes/ethyl acetate (4:1) as eluent, gave compound $2 \mathbf{d}$ (32 $\mathrm{mg}, 80 \%)$ as a yellow solid; mp $81-83{ }^{\circ} \mathrm{C} ;{ }^{1} \mathrm{H}-\mathrm{NMR}\left(300 \mathrm{MHz}, \mathrm{CDCl}_{3}\right.$, $25{ }^{\circ} \mathrm{C}$ ) $\delta: 7.24$ (dd, $\left.J=8.1,1.2 \mathrm{~Hz}, 1 \mathrm{H}\right), 7.08$ (dd, $J=7.3$, $1.2 \mathrm{~Hz}, 1 \mathrm{H}), 6.98$ (t, $J=7.7 \mathrm{~Hz}, 1 \mathrm{H}), 5.97$ (m, 1H), 4.99 and 4.89 (dt, $J=12.4,1.9 \mathrm{~Hz}$, each $1 \mathrm{H}), 3.56(\mathrm{~s}, 3 \mathrm{H}), 1.44(\mathrm{~m}$, $1 \mathrm{H}) ;{ }^{13} \mathrm{C}-\mathrm{NMR}\left(75 \mathrm{MHz}, \mathrm{CDCl}_{3}, 25{ }^{\circ} \mathrm{C}\right) \delta: 175.9,139.7$, 135.5, 132.2, 131.2, 125.1, 123.9, 123.0, 115.7, 91.8, 76.5, 29.7, 11.1; IR $\left(\mathrm{CHCl}_{3}, \mathrm{~cm}^{-1}\right): v$ 1734, 1461; HRMS (ES): calcd for $\mathrm{C}_{13} \mathrm{H}_{12} \mathrm{ClNO}_{2}[M]^{+}$: 249.0557; found: 249.0551 .

Dihydrofuran 2e. From $43 \mathrm{mg}(0.22 \mathrm{mmol})$ of allenol 1e, and after chromatography of the residue using hexanes/ethyl acetate (9:1) as eluent, gave compound $2 \mathbf{e}(26 \mathrm{mg}, 60 \%)$ as a colorless oil; ${ }^{1} \mathrm{H}-\mathrm{NMR}\left(300 \mathrm{MHz}, \mathrm{CDCl}_{3}, 25^{\circ} \mathrm{C}\right.$ ) $\delta: 7.32$ (d, $J=8.5 \mathrm{~Hz}, 2 \mathrm{H}), 7.21$ (d, $J=8.5 \mathrm{~Hz}, 2 \mathrm{H}), 5.65(\mathrm{~m}, 1 \mathrm{H})$, $5.46(\mathrm{~m}, 1 \mathrm{H}), 4.84$ and $4.71(\mathrm{~m}$, each $1 \mathrm{H}), 1.55(\mathrm{~m}, 3 \mathrm{H}) ;{ }^{13} \mathrm{C}-$ NMR $\left(75 \mathrm{MHz}, \mathrm{CDCl}_{3}, 25^{\circ} \mathrm{C}\right) \delta: 140.0,138.1,133.5,128.6$ (2C), 128.2 (2C), 121.0, 89.8, 75.5, 12.4; IR $\left(\mathrm{CHCl}_{3}, \mathrm{~cm}^{-1}\right)$ : $v$ 1730, 1684, 1091; HRMS (ES): calcd for $\mathrm{C}_{11} \mathrm{H}_{11} \mathrm{ClO}$ $[M]^{+}:$194.0498; found: 194.0506.

Dihydrofuran 2f. From $47 \mathrm{mg}(0.25 \mathrm{mmol})$ of allenol 1f, and after chromatography of the residue using hexanes/ethyl acetate (7:1) as eluent, gave compound $\mathbf{2 f}(22 \mathrm{mg}, 46 \%)$ as a yellow oil; ${ }^{1} \mathrm{H}-\mathrm{NMR}\left(300 \mathrm{MHz}, \mathrm{CDCl}_{3}, 25^{\circ} \mathrm{C}\right) \delta: 7.30(\mathrm{~d}$, $J=8.6 \mathrm{~Hz}, 2 \mathrm{H}), 6.89$ (d, $J=8.8 \mathrm{~Hz}, 2 \mathrm{H}), 5.05(\mathrm{t}, J=2.5 \mathrm{~Hz}$, $1 \mathrm{H}), 4.92$ (m, 2H), 3.81 (s, 3H), 1.55 (t, $J=3.1 \mathrm{~Hz}, 3 \mathrm{H})$; ${ }^{13} \mathrm{C}-\mathrm{NMR}\left(75 \mathrm{MHz}, \mathrm{CDCl}_{3}, 25{ }^{\circ} \mathrm{C}\right): 159.3,138.5,133.5$, 128.2 (2C), 120.6, 113.8 (2C), 90.1, 75.1, 55.2, 12.5; IR $\left(\mathrm{CHCl}_{3}, \mathrm{~cm}^{-1}\right)$ : 1609, 1511, 1248; HRMS (ES): calcd for $\mathrm{C}_{12} \mathrm{H}_{15} \mathrm{O}_{2}[M+\mathrm{H}]^{+}$: 191.1072; found: 191.1067.

Dihydrofuran 2g. From $47 \mathrm{mg}$ (0.21 mmol) of allenol 1g, and after chromatography of the residue using hexanes/ethyl acetate (6:1) as eluent, gave compound $\mathbf{2 g}$ (38 $\mathrm{mg}, 83 \%)$ as a colorless oil; ${ }^{1} \mathrm{H}-\mathrm{NMR}\left(300 \mathrm{MHz}, \mathrm{CDCl}_{3}, 25^{\circ} \mathrm{C}\right) \delta: 6.44$ (d, $J=2.2 \mathrm{~Hz}, 2 \mathrm{H}), 6.40(\mathrm{~m}, 1 \mathrm{H}), 5.63(\mathrm{~m}, 1 \mathrm{H}), 5.41$ (m, $1 \mathrm{H}), 4.84$ and $4.70(\mathrm{~m}$, each $1 \mathrm{H}), 3.79(\mathrm{~s}, 6 \mathrm{H}), 1.58(\mathrm{~m}, 3 \mathrm{H})$; ${ }^{13} \mathrm{C}-\mathrm{NMR}\left(75 \mathrm{MHz}, \mathrm{CDCl}_{3}, 25{ }^{\circ} \mathrm{C}\right) \delta: 160.9(2 \mathrm{C}), 143.9$, 138.4, 120.8, 104.7 (2C), 99.8, 90.5, 75.4, 55.3 (2C), 12.5; IR $\left(\mathrm{CHCl}_{3}, \mathrm{~cm}^{-1}\right): v$ 1596, 1153; HRMS (ES): calcd for $\mathrm{C}_{13} \mathrm{H}_{17} \mathrm{O}_{3}[M+\mathrm{H}]^{+}$: 221.1178; found: 221.1175.

Dihydrofuran $2 \mathbf{h}$. From $45 \mathrm{mg}(0.20 \mathrm{mmol})$ of allenol $\mathbf{1 h}$, and after chromatography of the residue using hexanes/ethyl acetate (3:1) as eluent, gave compound $\mathbf{2 h}$ (26 mg, 60\%) as a colorless oil; ${ }^{1} \mathrm{H}-\mathrm{NMR}\left(300 \mathrm{MHz}, \mathrm{CDCl}_{3}, 25^{\circ} \mathrm{C}\right) \delta: 8.16$ (d, $J=8.4 \mathrm{~Hz}, 2 \mathrm{H}), 7.17$ (m, 2H), $5.38(\mathrm{~m}, 1 \mathrm{H}), 5.13$ (q, $J=$ $1.6 \mathrm{~Hz}, 1 \mathrm{H}), 4.61$ (m, 2H) 3.50 (s, 3H), 1.23 (t, $J=1.3 \mathrm{~Hz}$, $3 \mathrm{H}) ;{ }^{13} \mathrm{C}-\mathrm{NMR}\left(75 \mathrm{MHz}, \mathrm{CDCl}_{3}, 25^{\circ} \mathrm{C}\right) \delta: 137.0,147.9$, 138.8, 130.7, 130.5, 127.3, 121.7, 90.5, 76.1, 51.9, 12.6; IR $\left(\mathrm{CHCl}_{3}, \mathrm{~cm}^{-1}\right): v 1723,1281,1112$; HRMS (ES): calcd for $\mathrm{C}_{13} \mathrm{H}_{14} \mathrm{O}_{3}[M]^{+}$: 218.0943; found: 218.0938.

Dihydrofuran 2i. From $40 \mathrm{mg}(0.16 \mathrm{mmol})$ of allenol 1i, and after chromatography of the residue using hexanes/ethyl acetate (7:1) as eluent, gave compound $\mathbf{2} \mathbf{i}(28 \mathrm{mg}, 71 \%)$ as a colorless oil; ${ }^{1} \mathrm{H}-\mathrm{NMR}\left(300 \mathrm{MHz}, \mathrm{CDCl}_{3}, 25^{\circ} \mathrm{C}\right) \delta: 7.35$ (s, 4H), 7.14 (m, 3H), 7.09 (d, $J=3.0 \mathrm{~Hz}, 2 \mathrm{H}), 6.05$ (td, $J=$ 4.6, $1.8 \mathrm{~Hz}, 1 \mathrm{H}), 5.98$ (q, $J=1.9 \mathrm{~Hz}, 1 \mathrm{H}), 4.76$ (d, $J=1.9$ $\mathrm{Hz}, 1 \mathrm{H}), 4.74$ (m, 1H); ${ }^{13} \mathrm{C}-\mathrm{NMR}\left(75 \mathrm{MHz}, \mathrm{CDCl}_{3}, 25{ }^{\circ} \mathrm{C}\right)$ $\delta: 146.7,141.3,133.0,132.7,129.0,128.6,128.5,127.2$, 124.2, 119.0, 112.8, 87.9, 76.1; IR $\left(\mathrm{CHCl}_{3}, \mathrm{~cm}^{-1}\right): v 2230$ 1758, 843; HRMS (ES): calcd for $\mathrm{C}_{17} \mathrm{H}_{13} \mathrm{NO}[M]^{+}$: 247.0997; found: 247.1005 .

Dihydrofuran 2j. From $47 \mathrm{mg}(0.27 \mathrm{mmol})$ of allenol 1j, and after chromatography of the residue using hexanes/ethyl acetate (9:1) as eluent, gave compound $\mathbf{2} \mathbf{j}$ (24 $\mathrm{mg}, 50 \%)$ as a colorless oil; ${ }^{1} \mathrm{H}-\mathrm{NMR}\left(300 \mathrm{MHz}, \mathrm{CDCl}_{3}, 25^{\circ} \mathrm{C}\right) \delta: 7.25$ (m, 5H), 5.44 (q, $J=1.6 \mathrm{~Hz}, 1 \mathrm{H}), 4.88(\mathrm{~m}, 1 \mathrm{H}), 4.46(\mathrm{~m}$, 2H), 3.01 (dd, $J=14.1,3.9 \mathrm{~Hz}, 1 \mathrm{H}$ ), 2.72 (dd, $J=14.1,6.8$ $\mathrm{Hz}, 1 \mathrm{H}), 1.74$ (m, 3H); ${ }^{13} \mathrm{C}-\mathrm{NMR}\left(75 \mathrm{MHz}, \mathrm{CDCl}_{3}, 25{ }^{\circ} \mathrm{C}\right.$ ) $\delta: 138.2,137.5,129.4$ (2C), 128.0 (2C), 126.0, 121.3, 88.1, 
74.4, 40.4, 12.7; IR $\left(\mathrm{CHCl}_{3}, \mathrm{~cm}^{-1}\right): v$ 1759, 1081, 1027; HRMS (ES): calcd for $\mathrm{C}_{12} \mathrm{H}_{14} \mathrm{O}[M]^{+}$: 174.1045; found: 174.1041.

Dihydrofuran 2k. From $40 \mathrm{mg}(0.12 \mathrm{mmol})$ of allene $\mathbf{1 k}$, and after chromatography of the residue using hexanes/ethyl acetate (3:1) as eluent gave compound $\mathbf{2 k}$ (26 $\mathrm{mg}, 64 \%)$ as a pale yellow oil: ${ }^{1} \mathrm{H}$ NMR (300 $\left.\mathrm{MHz}, \mathrm{CDCl}_{3}, 25^{\circ} \mathrm{C}\right) \delta$ : 8.50 (m, 1H), 8.02 (d, $J=7.9 \mathrm{~Hz}, 1 \mathrm{H}), 7.92$ (d, $J=8.2 \mathrm{~Hz}$, $1 \mathrm{H}), 7.78$ (td, $J=7.7,1.7 \mathrm{~Hz}, 1 \mathrm{H}), 7.57$ (s, 1H), 7.45 (d, $J=$ $7.6 \mathrm{~Hz}, 1 \mathrm{H}), 7.36$ (ddd, $J=7.7,4.7,1.0 \mathrm{~Hz}, 1 \mathrm{H}), 7.18$ (m, 2H), $5.66(\mathrm{~m}, 2 \mathrm{H}), 4.76$ and $4.71(\mathrm{~m}$, each $1 \mathrm{H}), 1.52(\mathrm{~s}, 3 \mathrm{H})$; ${ }^{13} \mathrm{C}-\mathrm{NMR}\left(75 \mathrm{MHz}, \mathrm{CDCl}_{3}, 25^{\circ} \mathrm{C}\right) \delta: 155.3,150.5,138.1$, 137.1, 136.0, 129.1, 127.6, 125.8, 124.8, 123.5, 122.3, 121.8, 121.6, 120.2, 113.9, 83.5, 75.2, 15.5; IR (CHCl3, $\left.\mathrm{cm}^{-1}\right): v$ 2850, 1377, 1188; HRMS (ES) calcd for $\mathrm{C}_{18} \mathrm{H}_{17} \mathrm{~N}_{2} \mathrm{O}_{3} \mathrm{~S}[M$ $+\mathrm{H}]^{+}$341.0960, found 341.0954.

Dihydrofuran 2l. From $40 \mathrm{mg}$ (0.09 mmol) of allene 1l, and after chromatography of the residue using hexanes/ethyl acetate (3:1) as eluent gave compound $2 \mathbf{l}$ (21 mg, 56\%) as a pale yellow oil: ${ }^{1} \mathrm{H}-\mathrm{NMR}\left(300 \mathrm{MHz}, \mathrm{CDCl}_{3}, 25^{\circ} \mathrm{C}\right.$ ) $\delta: 8.58$ (m, 1H), 8.09 (dt, $J=7.9,0.9 \mathrm{~Hz}, 1 \mathrm{H}), 7.89$ (m, 2H), 7.63 (s, $1 \mathrm{H}$ ), 7.62 (d, $J=1.7 \mathrm{~Hz}, 1 \mathrm{H}$ ), 7.47 (ddd, $J=7.7,4.7,1.1$ Hz, 1H), 7.38 (dd, $J=8.8,1.9$ Hz, 1H), 5.74 (m, 2H), 4.85 and $4.75(\mathrm{~m}$, each $1 \mathrm{H}), 1.59(\mathrm{t}, J=1.3 \mathrm{~Hz}, 3 \mathrm{H}) ;{ }^{13} \mathrm{C}-\mathrm{NMR}$ $\left(75 \mathrm{MHz}, \mathrm{CDCl}_{3}, 25^{\circ} \mathrm{C}\right) \delta 155.0,150.5,138.2,136.6,134.7$, 130.7, 127.7, 127.6, 126.8, 122.9, 122.2, 121.8, 121.0, 117.1, 115.4, 83.2, 75.2, 12.4; IR $\left(\mathrm{CHCl}_{3}, \mathrm{~cm}^{-1}\right): v$ 2992, 1381, 1188; HRMS (ES) calcd for $\mathrm{C}_{18} \mathrm{H}_{15} \mathrm{BrN}_{2} \mathrm{O}_{3} \mathrm{~S}[M]^{+}$ 417.9986, found 417.9971.

Carbazole 3m. From $40 \mathrm{mg}(0.18 \mathrm{mmol})$ of allenol 1m, and after chromatography of the residue using hexanes/ethyl acetate (8:1) as eluent gave compound 3m (25 mg, 71\%) as

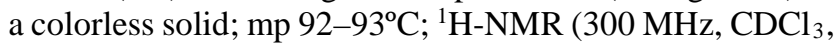
$\left.25^{\circ} \mathrm{C}\right) \delta: 7.96(\mathrm{~d}, J=7.8 \mathrm{~Hz}, 1 \mathrm{H}), 7.88(\mathrm{~d}, J=8.0 \mathrm{~Hz}, 1 \mathrm{H})$, 7.36 (m, 1H), 7.27 (d, $J=8.1 \mathrm{~Hz}, 1 \mathrm{H}), 7.13(\mathrm{~m}, 2 \mathrm{H}), 6.97$ (dd, $J=8.0,0.8 \mathrm{~Hz}, 1 \mathrm{H}), 3.72(\mathrm{~s}, 3 \mathrm{H}), 2.49$ (s, 3H); ${ }^{13} \mathrm{C}-$ NMR (75 MHz, $\left.\mathrm{CDCl}_{3}, 25^{\circ} \mathrm{C}\right): \delta: 142.0,141.4,136.3$, 125.5, 123.8, 120.9, 120.8, 120.4 (2C), 119.1, 109.1, 108.7, 29.4, 22.7; IR $\left(\mathrm{CHCl}_{3}, \mathrm{~cm}^{-1}\right): v$ 1469, 1249, 701; HRMS (ES): calcd for $\mathrm{C}_{14} \mathrm{H}_{13} \mathrm{~N}[M]^{+}$: 195.1048; found: 195.1040 .

Carbazole 3n. From $40 \mathrm{mg}(0.16 \mathrm{mmol})$ of allenol 1n, and after chromatography of the residue using hexanes/ethyl acetate (6:1) as eluent gave compound $3 \mathbf{n}(20 \mathrm{mg}, 50 \%)$ as

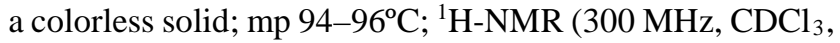
$\left.25^{\circ} \mathrm{C}\right) \delta$ : 7.92 (d, $\left.J=7.9 \mathrm{~Hz}, 1 \mathrm{H}\right), 7.55$ (d, $\left.J=2.4 \mathrm{~Hz}, 1 \mathrm{H}\right)$, 7.29 (s, $1 \mathrm{H}), 7.16$ (s, 1H), 7.08 (dd, $J=8.8,2.5 \mathrm{~Hz}, 1 \mathrm{H})$, 7.03 (d, $J=7.9 \mathrm{~Hz}, 1 \mathrm{H}), 3.93$ (s, 3H), 3.80 (s, 3H), 2.57 (s, $3 \mathrm{H}) ;{ }^{13} \mathrm{C}-\mathrm{NMR}\left(75 \mathrm{MHz}, \mathrm{CDCl}_{3}, 25^{\circ} \mathrm{C}\right): \delta: 153.5,141.9$, 136.0, 135.8, 123.0, 120.2, 119.8 (2C), 114.0, 108.9, 108.7, 103.2, 56.1, 29.0, 22.2; IR $\left(\mathrm{CHCl}_{3}, \mathrm{~cm}^{-1}\right): v$ 1486, 1287; HRMS (ES): calcd for $\mathrm{C}_{15} \mathrm{H}_{15} \mathrm{NO}[M]^{+}$: 225.1154; found: 225.1153.

Typical procedure for the recovery and recyclability of PdNPs. Upon completion of the reaction (monitored by TLC) of the appropriate allenol (1 $\mathrm{mmol})$, the reaction mixture was allowed to cool to room temperature and was diluted with ethyl acetate ( $2 \times 5 \mathrm{~mL})$. The aqueous layer which contains the Pd nanoparticles, was separated from the organic layer. The particles were collected by centrifugation and redispersed again in water. Then, the corresponding allenol 1 (1 mmol) and 4-bromophenol (1 mmol) were added. The reaction mixture was stirred at $60{ }^{\circ} \mathrm{C}$ until the starting material disappeared as indicated by TLC. The mixture was diluted with ethyl acetate $(3 \times 5 \mathrm{~mL})$ and the ethyl acetate layer was separated from the aqueous layer. The organic extract was dried over anhydrous $\mathrm{MgSO}_{4}$ and concentrated under reduced pressure. Chromatography of the residue using hexanes/ethyl acetate mixtures gave analytically pure compounds. The process was repeated for four consecutive times.

\section{Acknowledgements}

Support for this work by MINECO and FEDER (Projects CTQ2012-33664-C02-01, CTQ2012-33664-C02-02, CTQ201565060-C2-1-P, and CTQ2015-65060-C2-2-P), and CAM (Program GEOMATERIALS-2-2013/MIT-2914). We thank $M$. Elena de Orbe for preliminary studies.

\section{References}

[1] For a themed issue in allene chemistry, see: a) Progress in Allene Chemistry, (Eds.: B. Alcaide, P. Almendros), Chem. Soc. Rev. 2014, 43, 2879-3205 (issue 9, themed collections). For selected reviews on allene chemistry, see: b) L. Fensterbank, M. Malacria, Acc. Chem. Res. 2014, 47, 953; c) T. Lechel, F. Pfrengle, H.-U. Reissig, R. Zimmer, ChemCatChem 2013, 5, 2100; d) S. Yu, S. Ma, Angew. Chem. 2012, 124, 3128; Angew. Chem. Int. Ed. 2012, 51, 3074; e) N. Krause, C. Winter, Chem. Rev. 2011, 111, 1994; f) A. S. K. Hashmi, Angew. Chem. 2000, 112, 3737; Angew. Chem. Int. Ed. 2000, 39, 3590.

[2] For a themed issue in nanotechnology for organic synthesis, see: issue 36, (Ed.: Y. Yamamoto), Tetrahedron, 2014, 36, 6038-6192.

[3] For reviews, see: a) R. Cano, A. F. Schmidt, G. P. McGlacken, Chem. Sci. 2015, 6, 5338; b) V. Polshettiwar, T. Asefa, Nanocatalysis: Synthesis and Applications, Wiley: New Jersey, 2013; c) I. Favier, D. Madec, E. Teuma, M. Gómez, Curr. Org. Chem. 2011, 15, 3127; d) Selective Nanocatalysts and Nanoscience: Concepts for Heterogeneous and Homogeneous Catalysis, (Eds.: A. Zecchina, S. Bordiga, E. Groppo), Wiley VCH, 2011.

[4] For selected reviews on organic reactions in aqueous media, see: a) Water in Organic Synthesis In Science of Synthesis, (Ed.: S. Kobayashi), Georg Thieme Verlag, Stuttgart, 2012; b) M.-O. Simon, C.-J. Li, Chem. Soc. Rev. 2012, 41, 1415; c) R. N. Butler, A. G. Coyne, Chem. Rev. 2010, 110, 6302; d) M. Lombardo, C. Trombini, Curr. Opin. Drug Disc. 2010, 13, 717; e) A. Chanda, V. V. Fokin, Chem. Rev. 2009, 109, 725; f) Organic Reactions in Water: Principles, Strategies and Applications (Ed.: U. M. Linström), Blackwell: Oxford, 2007; g) C. J. Li, L. Chen, Chem. Soc. Rev. 2006, 35, 68; h) M. C. Pirrung, Chem. Eur. J. 2006, 12, 1312; i) C. J. Li, Chem. Rev. 2005, 105, 3095; j) U. M. Lindström, 
Chem. Rev. 2002, 102, 2751; k) K. Manabe, S. Kobayashi, Chem. Eur. J. 2002, 8, 4095; l) S. Ribe, P. Wipf, Chem. Commun. 2001, 299; m) C. J. Li, T. H. Chan, Tetrahedron 1999, 55, 11149; n) L. A. Paquette in Green Chemistry: Frontiers in Benign Chemical Synthesis and Processing, (Eds.: P. T. Anastas, T. C. Williamson), Oxford University Press: New York, 1998.

[5] a) K.-S. Yeung, X.-S. Peng, J. Wu, R. Fan, X.-L. Hou In Progress in Heterocyclic Chemistry, (Eds.: G. W. Gribble, J. A. Joule), Elsevier: Oxford, 2013, Vol. 25, pp 183-215; b) H. N. C. Wong, X.-L. Hou, K.-S. Yeung, H. Huang In Modern Heterocyclic Chemistry, (Eds.: J. Alvarez-Builla, J. J. Vaquero, J. Barluenga), WileyVCH: Weinheim, Germany, 2011, pp 533-592; c) H. N. C. Wong, K.-S. Yeung, Z. Yang In Comprehensive Heterocyclic Chemistry III, (Eds.: A. R. Katritzky, C. A. Ramsden, E. F. V. Scriven, R. Taylor), Elsevier, 2008, Vol. 3, Ch. 3.06, pp 407-496; d) B. A. Keay, J. M. Hopkins, P. W. Dibble In Comprehensive Heterocyclic Chemistry III, (Eds.: A. R. Katritzky, C. A. Ramsden, E. F. V. Scriven, R. Taylor), Elsevier, 2008, Vol. 3, Ch. 3.08, pp 571-623; e) T. G. Kilroy, T. P. O’Sullivan, P. J. Guiry, Eur. J. Org. Chem. 2005, 4929; f) The Chemistry of Heterocycles: Structure, Reactions, Syntheses, and Applications, (Eds.: T. Eicher, J. S. Hauptmann), WileyVCH: Weinheim, 2003; g) A. T. Merrit, S. V. Ley, Nat. Prod. Rep. 1992, 9, 243.

[6] a) A. Hoffmann-Röder, N. Krause, Org. Lett. 2001, 3, 2537; b) A. S. K. Hashmi, M. C. Blanco, D. Fischer, J. W. Bats, Eur. J. Org. Chem. 2006, 1387; c) M. Brasholz, B. Dugovič, H.-U. Reissig, Synthesis 2010, 3855; d) B. Alcaide, P. Almendros, T. Martínez del Campo, M. C. Redondo, I. Fernández, Chem. Eur. J. 2011, 17, 15005; e) Y. He, X. Zhang, X. Fan, Chem. Commun. 2015, 51, 16263; f) X. Zhang, C. Fu, S. Ma, Org. Lett. 2011, 13, 1920; g) W. Kong, C. Fu, S. Ma, Eur. J. Org. Chem. 2010, 6545; h) M. Asikainen, N. Krause, Adv. Synth. Catal. 2009, 351, 2305; i) D. Xu, Z. Li, S. Ma, Chem. Eur. J. 2002, 8, 5012; j) C. Jonasson, A. Horváth, J.-E. Bäckvall, J. Am. Chem. Soc. 2000, 122, 9600.

[7] Carbazole derivatives feature peculiar biological activities. Besides, the carbazole ring is a key molecular motif in materials science. For selected reviews, see: a) A. W. Schmidt, K. R. Reddy, H.-J. Knölker, Chem. Rev. 2012, 112, 3193; b) J. Roy, A. K. Jana, D. Mal,
Tetrahedron 2012, 68, 6099; c) I. Bauer, H.-J. Knölker, Top. Curr. Chem. 2012, 309, 203; d) J. Li, A. G. Grimsdale, Chem. Soc. Rev. 2010, 39, 2399.

[8] a) B. Alcaide, P. Almendros, J. M. Alonso, I. Fernández, J. Org. Chem. 2013, 78, 6688; b) Y. Qiu, C. Fu, X. Zhang, S. Ma, Chem. Eur. J. 2014, 20, 10314; c) B. Alcaide, P. Almendros, J. M. Alonso, M. T. Quirós, P. Gadziński, Adv. Synth. Catal. 2011, 353, 1871; d) W. Kong, C. Fu, S. Ma, Chem. Commun. 2009, 4572.

[9] A. Leyva-Pérez, J. Oliver-Meseguer, P. Rubio-Marqués, A. Corma, Angew. Chem. 2013, 125, 11768; Angew. Chem. Int. Ed. 2013, 52, 11554.

[10] For a different strategy to carbazoles using palladium nanomaterials, namely, amination reactions, see: L. L. Chng, J. Yang, Y. Wei, J. Y. Ying, Chem. Commun. 2014, 50, 9049.

[11] a) O. Augusto, M. C. Bonini, A. M. Amanso, E. Linares, C. C. X. Santos, S. L. De Menezes, Free Radic. Biol. Med. 2002, 32, 841; b) R. E. Huie, C. L. Clifton, P. Neta, Radiat. Phis. Chem. 1991, 38, 477.

[12] A. Kumar, S. Mandal, S. P. Mathew, P. R. Selvakannan, A. B. Mandale, R. V. Chaudhari, M. Sastry, Langmuir 2002, 18, 6478.

[13] a) A. Rocoux, J. Schultz, H. Patin, Chem. Rev. 2002, 102, 3757; b) D. Astruc, F. Lu, J. R. Aranzaes, Angew. Chem. Int. Ed. 2005, 44, 7852.

[14] The division based on the observed size is an accepted criterion in nanocatalysis. They are named nanoparticles (NPs) when the size of the particles is $>2 \mathrm{~nm}$, while the category of nanoclusters (NCs) are reserved for a size $<2$ nm. See: H. Miyamura, H. Min, J.-F. Soulé, S. Kobayashi, Angew. Chem. 2015, 127, 7674; Angew. Chem. Int. Ed. 2015, 54, 7564.

[15] TOF for the reaction of substrate 1a catalyzed by PdNPs $=23.3 \mathrm{~h}^{-1}$. TOF for the reaction of substrate 1a catalyzed by homogeneous $\mathrm{PdCl}_{2}=0.15 \mathrm{~h}^{-1}$. TOFs values were calculated as mol product $/ \mathrm{mol}$ palladium/time (hours). 


\section{UPDATES}

Palladium Nanoparticles in Water: A Reusable Catalytic System for the Cycloetherification or Benzannulation of $\alpha$-Allenols

Adv. Synth. Catal. 2016, 358, Page - Page

Benito Alcaide,* Pedro Almendros,* Ana M. González, Amparo Luna, Sagrario Martínez-

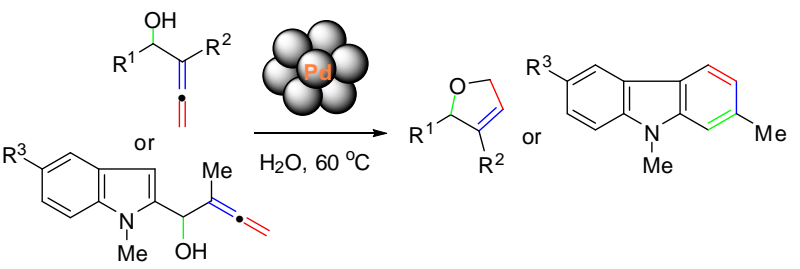
Ramírez

Autores (p.o. de firma): Alcaide, B.; Almendros, P.; González, A. M.; Luna, A.; Martínez-Ramírez, S.

Título: Palladium Nanoparticles in Water: A Reusable Catalytic System for the Cycloetherification or Benzannulation of $\alpha$-Allenols

Revista: Adv. Synth. Catal. 2016, 358, 2000-2006; DOI: 10.1002/adsc.201501132 